\title{
The Effect of Smartphone Addiction on Neck Pain and Disability in University Students
}

\author{
Üniversite Öğrencilerinde Akıllı Telefon Kullanımı Bağımlıı̆ının Boyun Ağrısı ve \\ Disabilite Üzerine Etkisi
}

\author{
Sevtap Badil Guloglu', Umit Yalcin² \\ ${ }^{1}$ Physical Medicine and Rehabilitation Department, Antalya Training and Research Hospital, Health Sciences University, Antalya; \\ ${ }^{2}$ Physical Medicine and Rehabilitation Department, Medicana International Istanbul Hospital, Istanbul, Turkey
}

\begin{abstract}
Aim: This study was planned to investigate the relationship between neck pain and disability with smartphone use addiction.

Material and Method: 501 students from Kars Kafkas University and Istanbul Biruni University were included in the study. Inclusion criteria were being a university student, being a smartphone user, and not having any history of systemic, neurological or psychiatric diseases. All participants were evaluated with smartphone addiction scale (SAS), Visuel Analogue Scale (VAS) and Neck Disability Index (NDI) for neck pain.
\end{abstract}

Results: The mean age of the 501 university students included was $21.0 \pm 1.9 .57 .7 \%$ of the participants were female and $42.3 \%$ were male. The mean VAS of the neck pain was $3.8( \pm 2.2)$, the mean SAS was $94.6( \pm 27.1)$, and the mean NDI was $10.6( \pm 7.0)$. Significant difference was not found between the genders in terms of SAS scores ( $p>0.05)$. The VAS and SAS scores were significantly higher in the moderate-severe-totally disability group than the mild disability and non-disability group ( $p>0.05$ ). According to spearman correlation analysis, there was a significant positive correlation between SAS and VAS and NDI scores ( $p$ value 0.005 , 0.001 , respectively).

Conclusion: Addiction to smartphone use was associated with neck pain and disability in healthy young adults. These results reveal the importance of informing the society about the physical risks of smartphone addiction. Individuals should strive to reduce the time spent using a smartphone and try to maintain a proper posture during use.

Key words: neck pain; smartphone addiction; student

\section{ÖZET}

Amaç: Bu çalıșma akılı telefon kullanımı bağımlıı̆ı ile boyun ağrısı ve disabilite arasındaki ilișkiyi araștırmak amacıyla planlandı.

Materyal ve Metot: Kars Kafkas Üniversitesi ve istanbul Biruni Üniveristesi'nde öğrenim gören 501 öğrenci çalıșmaya dahil edildi. Üniversite öğrencisi olmak, akıllı telefon kullanıcısı olmak, herhangi bir sistemik, nörolojik ve psikiyatrik hastalık öyküsü olmaması dahil edilme kriterleriydi. Tüm katıımcılar akıllı telefon bağımııı̆ı ölçeği (SAS), boyun ağrısına ilișkin Visuel Analog Skala (VAS) ve Neck Disability Index (NDI) ile değerlendirildi.

Bulgular: Dahil edilen 501 üniversite öğrencisinin yaș ortalaması 21,0 1,9 idi. Katılımcıların \%57,7'si kadın, \%42,3'ü erkekti. Katılımcıların boyun ağrısı VAS ortalaması 3,8 $( \pm 2,2)$, SAS ortalaması 94,5 ( $\pm 27,2)$, NDI ortalaması 10,6 $( \pm 7,0)$ olarak bulundu. Cinsiyetler arasında SAS skorları açısından anlamlı farklılık saptanmadı ( $p>0,05)$. Orta-șiddetli-tamamen özürlülük olan grupta VAS skoru, SAS skoru hafif özürlülük ve özürlülük olmayan gruptan anlamlı $(p>0,05)$ olarak daha yüksekti. Yapılan spearman korelasyon analizine göre SAS ile VAS ve NDI skoru arasında anlamlı pozitif korelasyon mevcuttu (p değeri sırasıyla 0,005, 0,001).

Sonuç: Akıllı telefon kullanımına bağımlılığın sağlıkı genç erișkinlerde boyun ağrısı ve disabilite ile ilișkili olduğu görüldü. Bu sonuçlar akıllı telefon kullanımı bağımlıı̆ının yaratacağı fiziksel riskler konusunda toplumun bilgilendirilmesinin önemini ortaya koymaktadır. Bireyler bir akıllı telefon kullanarak harcanan zamanı azaltmak için çaba sarf etmeli ve kullanımı sırasında uygun bir duruș sürdürmeye çalıșmalıdır.

Anahtar kelimeler: akıllı telefon bağımılı̆ğı; boyun ağrısl; öğrenci

IIetișim/Contact: Sevtap Badil Guloglu, Physical Medicine and Rehabilitation Department, Antalya Training and Research Hospital, Health Sciences University, Antalya, Turkey • Tel:0532 2011008 • E-mail:drsevtapbadil@hotmail.com • Geliș/Received: 12.09.2019 • Kabul/Accepted:08.06.2020 ORCID: Sevtap Badıl Güloğlu, 0000-0003-4872-7519 • Umit Yalcin, 0000-0003-4799-2759 


\section{Introduction}

Today, smartphones developed in parallel with the advancements in technology have caused global transformations in our societies. These devices enable us to connect to the internet and listen to music, accesses e-mails, searched the internet, perform searches, take high quality photographs, play games, enjoy shopping and perform many more transactions ${ }^{1,2}$. Such opportunities have enabled users to gain access to information with great speed, improve their time-dependent tasks, benefit from the ease of sharing information and generally save time ${ }^{2}$. Recently, the frequency and duration of smartphone use has been increasing ${ }^{3}$ and it has been reported that people spend more than 20 hours a week messaging, sending e-mails, using social networks and communicating, and that this may indicate a serious dependence on smartphones ${ }^{4}$. Although there are no exact definitions of smartphone addiction, the problematic use of the phone can be defined as having continuous control of the phone, leading to disruption of responsibilities or daily tasks. Certainly, smartphones are among the most important non-drug addictions in today's world ${ }^{1}$.

A study conducted in our country reported that the rate of smartphone dependency among university students is $26.7 \%$ in men and $27.9 \%$ in women ${ }^{5}$. This situation has resulted in many negative outcomes, such as a weakening of face-to-face communication, increased individualization, addictive practices and psychological problems to name a few ${ }^{2,6}$. In addition, musculoskeletal problems have reportedly increased with the expanded use of smartphones ${ }^{7,8}$. Therefore, health professionals should be aware of the impact of smartphone use on physical health problems $s^{9,10}$.

It has been reported that long and frequent smartphone use causes postural changes and proprioception deficits in cervical vertebrae ${ }^{8}$. The use of such devices, usually below the eye level, is the main factor contributing to the increase in the prevalence of neck pain and neck problems ${ }^{9,11,12}$.

As far as we were able to determine, there exists no studies examining the relationship between neck pain and disability related to smartphone use addiction in our country. This study was therefore designed and conducted in order to investigate this potential correlation.

\section{Material and Method}

Five hundred one (501) university students, from two institutions in two different regions, were included in this cross-sectional study, on a voluntary basis. Students from these different cities with different socio-cultural characteristics, habits and lifestyles were included in order to reflect the wider community. The research protocol was approved by the local ethics committee (date of acceptance: 27.02.19, decision no: 09). After all participants were informed about the study, written, informed consent was obtained and all stages of the study were sustained in accordance with the Declaration of Helsinki. Three (3) inclusion criteria applied were that the participants be enrolled in university, that they be smartphone users, and that they did not have any history of systemic, neurological or psychiatric diseases.

The age and gender of all participants were recorded. All participants were evaluated with Visual Analogue Scale (VAS) in terms of the severity of neck pain, Neck Disability Index (NDI) in terms of the effect of neck pain on daily living activities and Smartphone Addiction Scale (SAS) in terms of smartphone use dependence. Participants were divided into three groups defined as "non-disability", "mild disability", and "moderate-to-complete disability".

\section{Visual Analogue Scale (VAS)}

Pain and numbness for daytime and night were evaluated with the use of a visual analogue scale (VAS). The patient was asked to mark the severity of pain on a 100 mm line using "no pain" on one end and "most unbearable pain" on the other end. The distance from the starting point of the pain to the point marked by the patient was recorded.

\section{Neck Disability Index (NDI)}

The Neck Disability Index (NDI), the Turkish validity and reliability of which was performed by Telci et al., was used to evaluate neck pain and functional disability $^{13}$. This is a self-rating Likert-type questionnaire consisting of 10 items (neck pain, self-care, load lifting, reading, headache, concentration, work, driving, sleeping, and free-time activities), each scored between 0 and 5 . The total score ranges from 0 to 50 , and higher scores demonstrating the worse disability ${ }^{14}$. According to the test results, there would be no disability between 0-4, a mild disability between 5-14, a moderate 
Table 1. Demographic characteristics of participants

\begin{tabular}{|c|c|c|c|c|}
\hline & Min-Max & Median & $A v g \pm s . d$ & $\mathrm{n}-\%$ \\
\hline Age & $18.0-40.0$ & 21.0 & $21.0 \pm 1.9$ & \\
\hline $\begin{array}{ll}\text { Gender }(n-\%) & \begin{array}{l}\text { Female } \\
\text { Male }\end{array}\end{array}$ & & & & $\begin{array}{l}289-57.7 \% \\
212-42.3 \%\end{array}$ \\
\hline VAS & $0.0-10.0$ & 4.0 & $3.8 \pm 2.2$ & \\
\hline SAS & $35.0-180.0$ & 93.0 & $94.6 \pm 27.1$ & \\
\hline NDI & $0.0-35.0$ & 9.0 & $10.6 \pm 7.0$ & \\
\hline No disability (n - \%) & & & & $99-19.8 \%$ \\
\hline Mild disability (n - \%) & & & & $279-55.7 \%$ \\
\hline Moderate disability $(\mathrm{n}-\%)$ & & & & $97-19.4 \%$ \\
\hline Severe disability $(n-\%)$ & & & & $25-5.0 \%$ \\
\hline Comlete disability (n - \%) & & & & $1-0.2 \%$ \\
\hline
\end{tabular}

Min, minimum; Max, maximum; avg, average; sd, standart deviation; VAS, visual analogue scale; SAS, smartphone addiction scale; NDI, neck disability index

disability between 15-24, a severe disability between 25-34, and a complete disability at 35 and over. As indicated earlier, participants were divided into three groups defined as "non-disability", "mild disability", and "moderate-to-complete disability".

\section{Smartphone Addiction Scale (SAS)}

The Smartphone Addiction Scale (SAS) is a self-rating scale consisting of 33 items and developed by Kwon et al. ${ }^{8}$. Each item is evaluated with a Likert-type scale ranging from 1 (definitely not) to -6 (absolutely yes). The distribution of points to be obtained from this scale is between 33 and 198 points, whereas the scale consists of 6 subscales: daily life disorders (5 items), positive anticipation ( 8 items), withdrawal (6 items), cyberspace-oriented relationship (7 items), overuse ( 4 items), and tolerance (3 items). Higher scores indicate a more serious smartphone addiction and a cut-off value is not given in its original form. The developers of the scale found that the internal consistency of the scale was Cronbach $\alpha=0.967^{\circ}$; the Turkish validity and reliability was performed by Demirci et $\mathrm{a}^{15}$.

\section{Statistical Analysis}

Mean, standard deviation, median, lowest, highest, frequency and ratio values were used in the descriptive statistics of the data. The distribution of variables was measured using the Kolmogorov Simirnov test and the Kruskal-Wallis, Mann-Whitney U test was used for the analysis of the quantitative independent data. The Chisquare test was used for the analysis of qualitative independent data. The Spearman correlation analysis was used to determine the relationship between SAS, NDI and VAS. SPSS 22.0 software for Windows program (SPSS, Chicago, IL, US) was used for the analysis. The statistical significance level was accepted as $\mathrm{p}<0.05$.

\section{Results}

The results regarding the demographic characteristics of the students participating in the research are given in Table 1. As indicated previously, the mean age of the 501 university students included was $21 \pm 1.9$ years (min $18, \max 40)$ and $57.7 \%$ of the participants were female, whereas $42.3 \%$ were male (Table 1 ).

The mean VAS of the neck pain of the participants was $3.8 \pm 2.2$, the mean SAS score was $94.6 \pm 27.2$, and the mean NDI score was $10.6 \pm 7.0$. There was no significant difference between the genders in terms of NDI and SAS scores ( $p>0.05)$ (Table 1); neck disability levels of the participants, according to the NDI, are summarized in Table 2.

Table 2. Comparison of SAS and NDI scores in terms of gender

\begin{tabular}{lccc}
\hline & \multicolumn{2}{c}{ Gender } & \\
\cline { 2 - 3 } & Female & Male & P \\
\hline SAS (Mean \pm sd) & $92.9 \pm 26.8$ & $96.9 \pm 27.4$ & $0.099^{\mathrm{t}}$ \\
& & & \\
NDI (Median (Min-Max)) & $9(0-35)$ & $9(0-30)$ & $0.235^{\mathrm{m}}$ \\
\hline $\begin{array}{l}\text { SAS, smartphone addiction scale; NDI, neck disability index; sd, standart deviation; t, student t } \\
\text { test; m, Mann-Whitney U test. }\end{array}$
\end{tabular}


Table 3. Comparison of groups according to neck disability

\begin{tabular}{|c|c|c|c|c|c|c|c|c|c|c|c|c|}
\hline & & & & & & Neck Disabilit & & & & & & \\
\hline & & No d & sability $(n=99$ & & Mild & isability $(n=2$ & & Modarete-s & vere-comlete & $=123)$ & & \\
\hline & & Avg. \pm s.d & $n-\%$ & Median & Avg. \pm s.d & $n-\%$ & Median & Avg. \pm s.d & $\mathrm{n}-\%$ & Median & $p$ & \\
\hline Age & & $21.0 \pm 2.0$ & & 21.0 & $21.1 \pm 2.0$ & & 21.0 & $20.9 \pm 1.7$ & & 21.0 & 0.391 & k \\
\hline Gender & Female & & $50-50.5 \%$ & & & $170-60.9 \%$ & & & $69-56.1 \%$ & & 0.181 & $x^{2}$ \\
\hline & Male & & $49-49.5 \%$ & & & $109-39.1 \%$ & & & $54-43.9 \%$ & & & \\
\hline VAS & & $2.7 \pm 1.8$ & & 3.0 & $3.7 \pm 1.9$ & & 4.0 & $4.9 \pm 2.4$ & & 5.0 & 0.001 & k \\
\hline SAS & & $81.4 \pm 24.8$ & & 83.0 & $96.3 \pm 25.7$ & & 94.0 & $101.3 \pm 28.6$ & & 99.0 & 0.001 & k \\
\hline
\end{tabular}

Avg, average; sd, standart deviation; VAS, Visual Analogue Scale; SAS, Smartphone Addiction Scale; ${ }^{k}$, Kruskal Wallis test (Mann Whitney U), X², chi-square test (Pearson).

Participants were divided into the three predefined groups ("non-disability", "mild disability", and "moderate-to-complete disability") according to their NDI scores. We found no significant difference between the groups in terms of age and gender $(\mathrm{p}>0.05)$ (Table $3)$, however when these three groups were compared in terms of the VAS scores, a statistically significant difference was found between them: in the "moderate-to-complete disability" group, the VAS score was significantly higher than in the "mild disability" and "non-disability" groups $(\mathrm{p}=0.001)$ (Table 3).

According to the spearman correlation analysis, there was a significant positive correlation between SAS with VAS and NDI scores ( $p=0.005,0.001$, respectively). No significant correlation was found between age and VAS, age and NDI, age and SAS scores $(p>0.05)$ (Table 4).

\section{Discussion}

In this study, the effect of smartphone use on neck pain and disability was evaluated in university students. Addiction to smartphone use was found to be associated with neck pain and disability in healthy young adults. There was a significant correlation between the SAS and NDI scores which evaluated neck disability and these results are consistent with previous studies showing the frequency of musculoskeletal symptoms associated with computer use and that smartphone use causes physical health-related problems ${ }^{8,16-19}$.

Smartphones have become an inseparable part of daily life with the increase in the conveniences it provides to individuals. However, in addition to these, smartphone addiction, which may develop due to excessive use, is an issue that needs to be addressed in a significant way, such as has been done for alcohol, cigarette and drug addictions ${ }^{20,21}$. In studies published in recent years, it was reported that musculoskeletal symptoms increased with the addiction of smartphones ${ }^{10,22}$. The most frequent musculoskeletal pain region being accounted in these studies was neck $^{10,22,23}$. Although previous studies have found a correlation between computer use and neck pain ${ }^{24}$, recent studies have found that the frequency and severity of neck problems is higher in smartphone use, compared to computer use ${ }^{25}$.

Recurrent and prolonged neck flexion is one of the factors that increase the risk of neck pain and disability ${ }^{26,27}$. A frequent, recurrent neck flexion posture affects natural angle of the cervical spine, increases the stress to which the cervical spine is exposed ${ }^{28}$, leads to proprioception losses in the cervical vertebra ${ }^{29}$ and leads to spasm in muscles and ligaments ${ }^{30}$. In some studies, it was reported that in addition to neck flexion angle, the head tilt angle and forward head shifting increased with the use of smartphones ${ }^{31,32}$. These

Table 4. Correlation of age, VAS, NDI and SAS scores

\begin{tabular}{ccccc}
\hline & & VAS & SAS & Age \\
\hline NDI & $r$ & 0.326 & 0.237 & -0.018 \\
& $p$ & $\mathbf{0 . 0 0 0}$ & $\mathbf{0 . 0 0 1}$ & 0.685 \\
VAS & $r$ & & 0.124 & -0.057 \\
& $p$ & & 0.005 & 0.200 \\
SAS & $r$ & & & 0.042 \\
& $p$ & & & 0.353 \\
\hline
\end{tabular}

Spearman test; VAS, visual analogue scale; SAS, smartphone addiction scale; NDI, neck disability index. 
conditions are associated with an increased risk of chronic neck pain ${ }^{33}$ and may explain the relationship found between the NDI and SAS $S^{9,10,18}$. A study conducted in 2017 showed that smartphone addiction was associated with neck problems and disability in healthy young people ${ }^{18}$. In support of these results, this study being the first carried out in our country in this regard, we obtained a positive correlation between the VAS, NDI and SAS scores and at the same time, the SAS scores of the patients with moderate-severe-complete neck disability were found to be significantly higher.

In a study conducted on 289 nursing students in a public university, it was reported that gender factors did not affect the level of smartphone addiction ${ }^{34}$. A result which was sustained by another study, this time conducted with the participation of 367 university students, showing that there was no difference in terms of smartphone addiction levels between female and male students ${ }^{35}$. We have found similar result in our study.

The importance of this study stems from the fact that it is the first to investigate the relationship between smartphone addiction and neck disability in Turkey and that the participants were free from any systemic, neurological or psychiatric illnesses. We also believe that the inclusion of students from two institutions found in different geographical regions, Kars and Istanbul, is significant.

While further large-scale studies are needed to more deeply examine the scientific facts on this subject, as a result of our study, a significant relationship was found between smartphone addiction and neck pain level and neck disability. Posture disorders associated with smartphone use can indeed reveal neck disabilities; minimally, these results highlight the importance of informing users about the physical risks associated with smartphone addiction, who should be encouraged to make efforts to reduce the time spent with the smartphone and maintain proper posture while using it.

\section{Limitations}

The cross-sectional design of our study constitutes a limitation, as were unable to create a causal link the relationship between smartphone addiction and neck pain and disability. Another limitation may be found in the fact that we did not examine the possibility that other reasons may have affected neck disabilities in our participants, such as computer screen usage, television viewing positions, backpack usage and desk work.
Therefore, well-controlled prospective studies are required to confirm the results of this study.

\section{References}

1. Hosgor H, Tandogan O. Effect of Nomophobia on duration of daily smartphone usage and school success: The example of health personnel candidates. The Journal of Academic Social Science 2017;46(5):573-95.

2. Haug S, Castro RP, Kwon M, Filler A, Kowatsch T, Schaub MP. Smartphone use and smartphone addiction among young people in Switzerland. J Behav Addict 2015;4(4):299-307.

3. Grant JE, Lust K, Chamberlain SR. Problematic smartphone use associated with greater alcohol consumption, mental health issues, poorer academic performance, and impulsivity. J Behav Addict 2019;8(2):335-342.

4. Madge C, Meek J, Wellens J, Hooley T. Facebook, social integration and informal learning at university: 'It is more for socialising and talking to friends about work than for actually doing work. Learn Media Technol 2009;34(2):141-55.

5. Demirci K, Demirci S, Akgönül M. Headache in Smartphone Users: A Cross-Sectional Study. J Neurol Psychol 2016;4(1):5.

6. Tossell C, Kortum P, Shepard C, Rahmati A, Zhong L. Exploring Smartphone Addiction: Insights from Long Term Telemetric Behavioral Measures. Int J Interact Mob Technol 2015;9(2):37-43.

7. Ahmed S, Pokhrel N, Roy S, Samuel AJ. Impact of nomophobia: A nondrug addiction among students of physiotherapy course using an online cross-sectional survey. Indian J Psychiatry 2019;61(1):77-80.

8. Kwon M, Lee JY, Won WY, Park JW, Min JA, Hahn J et al. Development and Validation of a Smartphone Addiction Scale (SAS). Plos one 2013;8(2): e 56936.

9. Berolo S, Wells RP, Amick BC 3rd. Musculoskeletal symptoms among mobile hand-held device users and their relationship to device use: A preliminary study in a Canadian university population. Appl Ergon 2011;42(2):371-8.

10. Eitivipart AC, Viriyarojanakul S, Redhead L. Musculoskeletal disorder and pain associated with smartphone use: A systematic review of biomechanical evidence. Hong Kong Physiother J 2018;38(2):77-90.

11. Maniwa H, Kotani K, Suzuki S, Asao T. Changes in posture of the upper extremity through the use of various sizes of tablets and characters. In: Int Conf Human Interface and the Management of Information. Berlin, Heidelberg: Springer, 2013;89-96.

12. Gold JE, Driban JB, Yingling VR, Komaroff E. Characterization of posture and comfort in laptop users in non-desk settings. Appl Ergon 2012;43(2):392-9.

13. Telci EA, Karaduman A, Yakut Y, Aras B, Simsek IE, Yagli N. The cultural adaptation, reliability, and validity of neck disability index in patients with neck pain: a Turkish version study. Spine (Phila Pa 1976) 2009;34(16):1732-5. 
14. Vernon H, Mior S. The Neck Disability Index: a study of reliability and validity. J Manipulative Physiol Ther 1991;14(7):409-15.

15. Demirci K, Orhan H, Demirdas A, Akpınar A, Sert H. Validity and reliability of the Turkish Version of the Smartphone Addiction Scale in a younger population. Bulletin of Clinical Psychopharmacology 2014;24:226-234.

16. Jenkins M, Menéndez CC, Amick BC 3rd, Tullar J, Hupert N, Robertson MM, et al. Undergraduate college students' upper extremity symptoms and functional limitations related to computer use: a replication study. Work 2007;28(3):231-8.

17. Long J, Liu TQ, Liao YH, Qi C, He HY, Chen SB, Billieux J. Prevalence and correlates of problematic smartphone use in a large random sample of Chinese undergraduates. BMC Psychiatry 2016;16(1):408.

18. AlAbdulwahab SS, Kachanathu SJ, AlMotairi MS. Smartphone use addiction can cause neck disability. Musculoskeletal Care 2017;15(1):10-2.

19. Shah PP, Sheth MS. Correlation of smartphone use addiction with text neck syndrome and SMS thumb in physiotherapy students. Int J Community Med Public Health 2018;5:2512-6.

20. Ahmed S, Pokhrel N, Roy S, Samuel AJ. Impact of nomophobia: A nondrug addiction among students of physiotherapy course using an online cross-sectional survey. Indian J Psychiatry 2019;61(1):77-80.

21. Panova $T$, Carbonell $X$. Is smartphone addiction really an addiction? J Behav Addict 2018;7(2):252-9.

22. Elserty NS, Helmy NA, Mounir KM. Smartphone addiction and its relation to musculoskeletal pain in Egyptian physical therapy students. Eur J Physiother 2018. [Last accessed on 2019 Sep 17].

23. Alsalameh AM, Harisi MJ, Alduayji MA, Almutham AA, Mahmood FM. Evaluating the relationship between smartphone addiction/overuse and musculoskeletal pain among medical students at Qassim University. J Family Med Prim Care 2019;8(9):2953-9.

24. Sabeen F, Bashir MS, Hussain SI, Ehsan S. Prevalance of Neck Pain in Computer Users. Annals 2013;19(2):137-143.

25. Young JG, Trudeau M, Odell D, Marinelli K, Dennerlein JT. Touch-screen tablet user configurations and case-supported tilt affect head and neck flexion angles. Work 2012;41(1):81-91.
26. Lee S, Kang H, Shin G. Head flexion angle while using a smartphone. Ergonomics 2015;58(2):220-6.

27. Kuo YR, Fang JJ, Wu CT, Lin RM, Su PF, Lin CL. Analysis of a customized cervical collar to improve neck posture during smartphone usage: a comparative study in healthy subjects. Eur Spine J 2019;28(6):1793-1803.

28. Hansraj KK. Assessment of stresses in the cervical spine caused by posture andposition of the head. Surg Technol Int 2014;25:277-9.

29. Kim YG, Kang MH, KimJW, Jang JH, Oh JS. Influenceof the duration of smartphone usage on flexion angles of the cervicaland lumbar spine and on reposition error in the cervical spine. PhysicalTherapy Korea 2013;20(1), 10-7.

30. Fredriksson K, Alfredsson L, Ahlberg G, Josephson M, Kilbom Å, Hjelm EW et al. Work environment and neck and shoulder pain: The influence of exposure time. Results from a population based case-control study. Occupational and Environmental Medicine 2002;59(3), 182-88.

31. Guan X, Fan G, Wu X, Zeng Y, Su H, Gu G, et al. Photographic measurement of head and cervical posture when viewing mobile phone: a pilot study. Eur Spine J 2015;24(12):2892-8.

32. Kim MS. Influence of neck pain on cervical movement in the sagittal plane during smartphone use. J Phys Ther Sci 2015;27(1):15.

33. Zhuang L, Wang L, Xu D, Wang Z, Liang R. Association between excessive smartphone use and cervical disc degeneration in young patients suffering from chronic neck pain. J Orthop Sci. [published online ahead of print, 2020 Mar 20] 020;S09492658(20)30060-9.

34. Yılmaz D, Çinar HG, Özyazıcıoğlu N. The Examination of Relationship between Smart Phone, Internet Addiction and Upper Extremity Fuctional Activity Levels among Nursing Students. SDÜ Journal of Health Science 2017;8(3), 34-9.

35. Noyan CO, Darçın AE, Nurmedov S, Yılmaz O, Dilbaz N. Validity and reliability of the Turkish version of the Smartphone Addiction Scale-Short Version among university students. Anatolian Journal of Psychiatry 2015;16(Special issue 1):73-81. 